\title{
The Mission of Basic Education That Is Overlooked in the Border Country (Case Study of Education Special Services for Indonesian Labor Child in Sebatik Island Indonesia-Malaysia Border)
}

\author{
Hardi Warsono ${ }^{1}$ \\ ${ }^{1}$ Public Administration Department, Faculty of Social and Political Science, Diponegoro University, Semarang, \\ Central Java, Indonesia
}

Received: September 25, 2017

Accepted: October 10, $2017 \quad$ Online Published: December 27, 2017

doi:10.5539/ass.v14n1p59

URL: https://doi.org/10.5539/ass.v14n1p59

\begin{abstract}
The border region is currently still very identical to the "limitations" so almost all border regions in Indonesia have nearly the same issue namely welfare gaps to the Community border as a result of the limitations of the various issues of basic infrastructure, education, health issues to social economic problems communities are still largely dependent on neighboring countries. In the field of education is known for all education jargon that became the Foundation of the movement the fulfillment of education for all. In order to achieve the goals of national education the flattens, quality, relevant and efficient as mandated by legislation of the national education system the number 20 in 2003 , where special education and special services (PK-LK) need very basic education gets special attention. A labor of Indonesia (TKI) at the boundary of the country generally citizens of the entrants in the Emergency Department and is busy with his household economic activities. The condition implies less serious handling education for their child. This problem is compounded by the limited educational facilities at the border. To address this movement of strange education boundary is required.
\end{abstract}

Keywords: Social Movements, Education Special Service, and Border

\section{Introduction}

The impression of a lack attention from the Government towards the border area has always been associated with the development of the approach used in the past, that a greater emphasis on security (security) compared with increased prosperity (prosperity). If we notice on social condition, politic and security in the past, it creates a high impression into development border area which is emphasizing on aspect and security approach. While in this situation where security aspect is more conducive and a globalization process indicated by a lot of cooperation both of local economies or sub regional, in order a security approach need to be allowed through prosperity approach equally. In the other side, a lot of neighbor country bordering directly with Indonesia has developed their border area as an area of economical growth progressively through facility and physical infrastructure completely together with human resource who having quality.

The handling question of the border is not only become the responsibility of the Central Government, provincial government, and the Government district/city alone but also will need to be supported by all components of the nation both from the corporate world, community organizations and agencies/other technical institutions. Starting from the large number of issues in the border area, then needed an innovation and creativity from the organizers of Government at the level of districts and Villages as the Border becomes the home front of Indonesian Republic. The attitude of society to care about the borders should look for solutions and solving the problem.

Central Sebatik district as one of border district at Sebatik Island that is implement a lot of innovative activities aiming to decrease various problems faced by community border. Those innovations implemented classified into two fields such as Health and Education program. In the health field, have carried out Free Sub program Defecation carelessly. These activities were carried out as a form of concerned from the districts and villages of the border most of those houses have no Toilet/closet for Defecation in any place.

In the education field, have held Illiteracy eradication activities for the Community borders and border education activities for Indonesian Labor children working in Sebatik Malaysia as a labour company Palm. Activities in the education field is cooperation with education service District serving Nunukan, PKK Subdistrict Sebatik and Ar-Rasyid Foundation as one of the foundations in the Central Sebatik District concentrated and commit against the 
education frontier. Necessary social movements that can mobilize public attention Indonesia to address the Education problem of Indonesian Labor Child at the border.

The concept of this research are as follows: 1) to observe educational concept of This research aims to develop education concept in the border area in early childhood education (OLD), the movement of the eradication of illiteracy and education movement for Indonesia Labor Child /TKI, 2) how does the implementetation of education movement in the border area, 3) how does the stakeholders role in the implementation of educational movement. This research aims to develop educational concept in the border area. The stakeholder role into educational movement starts from an activist namely Mrs. Hj. Zuraidah as a midwife in the border area for community deliviring then supported by Non-Governmental Organization and Local Government.

\section{Previous Research}

\subsection{Border Education with emphasizing on Giroux 's Educative Implications}

\section{By: Mohsen Farmahini Farahania, Najmeh Ahmadabadi Arani}

Modern Socio-philosophical perspective has been arisen in the work of thinkers in recent decades which has been called postmodernism As this perspective introduces new issues in different areas, it poses new attitudes in the education area. Giroux who is a contemporary postmodernism Theory maker is going to introduce a kind of education in which culture, ethics and politics are very important. As he criticizes the present worldwide education which is based on modernized courses, he proposes border educative perspective. The present article explains his implications in education by an analytical-descriptive method. Findings showed that in his idea, education essentially has got political tendency and the goal of the border education is making a democratic society which is in favour of equality and detecting the borders, observing the differences and understanding them Education in which other voices are listened is a desired education. The reflection and philosophy of the border education cannot ignore the social and cultural issues of the people because it will fail without them. In the view of border education, we should trespass the mere transmission of understood knowledge in education and consider the teacher as the open-mindeds of the society and revolutionist.

\subsection{Feasibility Analysis of Developing Cross-border Network Education in China \\ By: Jun Lan}

In the era of economic globalization, strengthen of international cooperation on network education is a general trend. Although China has not made commitments about the market access and national treatment of cross-border supply in Schedule of Specific Commitments on Services, the basic conditions of network education development in China have been met. The Chinese government should formulate strategies for the development of cross-border network education and take relevant measures to implement them. In the near future, the carrying out of cross-border network education in China will become an irreversible trend, and will possess broad prospect with the advance of globalization of Chinese education.

2.3 The Study of Concepts Understanding and Using Competence of Teachers in Educational Innovation and Technology for Teaching Management at Schools of the Unrest Areas of Three Southern Border Provinces of Thailand

By: Kanita Nitjarunkul

This research study aimed to determine the understanding of concepts and use of competence of teachers in using educational innovation and technology (EIT) for teaching management. And also, to investigate the internal and external factors effecting teachers for applying EIT to their instructions at schools in the areas of unrest in three southern border provinces (3SBP) of Thailand. Questionnaire and group interview protocols were used. With $87 \%$ return rate of completed surveys, it is shown that (1) the level of concepts understanding of teachers in EIT for teaching management was at high, (2) Teachers working in different affiliations have statistically significant in using computer software and computer-based learning for teaching management, and (3) Teachers teaching under the Basic Education Commission school have a higher level of using competence in computer software and computer-based learning than teachers who teach under Islamic private school. Key findings from focus group discussions revealed strengths, weaknesses, opportunities and threats that effected teachers in applying EIT to their teaching.

\subsection{The Development of Cross-Border Cooperation in an EU Macroregion - a Case Study of the Baltic Sea Region}

\section{By: Tomasz Studzieniecki}

The Baltic Sea Region became an EU testing ground for international cooperation. This article presents the origin and the typologies of this cooperation. Macroregional, territorial and cross-border cooperation was discussed. The main aim of this article was to analyse the key determinants of the development of cross-border cooperation in the BSR, an EU macroregion. Based on literature studies, the BSR was delimited, proposing a definition of this area that is the 
most beneficial from economic point of view. Having performed an analysis of documents and economic data, it was proven that macroregional cooperation supports territorial cooperation in the BSR in a significant way. For this purpose, the financing devices of territorial cooperation, i.e. crossborder, transnational and interregional cooperation programmes, were analysed. It was proven that the priorities of these programmes comply with the priorities of the EU Strategy for the Baltic Sea Region. Furthermore, an attempt was made to analyse the organisational resources of cross-border cooperation, with particular focus on Euroregions and European groupings of territorial cooperation. A diagnosis of the state was made based on secondary and primary data obtained from interviews. It was shown that the organisational structure is not fully efficient, which is a barrier to the development of cross-border cooperation.

2.5 The Important Factors of English Program Administration Responsive to the ASEAN Community for Schools in the Border Provinces of Southern Thailand

\section{By: Wuttichai Niemted}

The purpose of this research was to determine the important factors utilizing the key principles of the Input-Process-Output (IPO) framework in the administration of English Programs for schools in the border provinces of southern Thailand in response to the protocols and agenda of the ASEAN community in its education platforms. The research explored various methods that involved analysis and interpretation of the quantitative and qualitative data obtained from the prepared 5-point rating scale questionnaire, interviews, and observation, target group discussion, and consultation with experts. The respondents selected as the sample group were English Program administrators, teachers, students, and parents from 5 selected English Program schools in the border provinces of southern Thailand for the academic 2013 year. Based on results gathered from both qualitative and quantitative methods, the important factors under the concept of the IPO framework consisted of 21 factors: Support-resource input consisted of 3 factors: integrating the curriculum with ASEAN community content, using technology as an effective teaching aid, and maximizing various learning resources. Personnel-resource input contained 2 factors: having a school director with a strong vision and understanding of bilingual education, and investing in qualified and professional teachers. School-management process highlighted 8 key factors: management structure, policy/vision, community involvement, school-networks, utilization of modern technology and classroom management for self-access learning, staff development, cultivation of the culture of research in the academy and student-centered activities that promote competence and quality assurance. Learning-management process consisted of 3 factors: learning patterns in the use of English and Thai as media of instruction, learning-management style, and measurement and evaluation. Output or educational quality entailed 5 determinants: learning achievement, attainment of the desirable characteristics of the learners, educational roles in society and culture, achievement of English skills among target groups in aspects of communication and research, and knowledge of the ASEAN community.

2.6 Integration Requirements for Integration's Sake? Identifying, Categorising and Comparing Civic Integration Policies

By: Sara Wallace Goodman

Several countries in Europe have recently adopted obligatory language and country knowledge requirements for settlement, naturalisation and immigration. Integration tests, courses and contracts are only a few examples of the new 'civic integration policies' states are using to promote individual autonomy and common values for newcomers. Are these requirements in response to concrete problems of immigrant integration? Do they enable, or actually inhibit, integration? This paper examines the various pressures behind attaching mandatory integration requirements to status acquisition. To systematically examine these policies, I develop a civic integration index (CIVIX) to measure language, country-knowledge and value-commitment requirements across the EU-15. While there is a general shift toward civic requirements across Europe, evidence reveals important differences in the degree of policy change. Finally, I explore how new civic requirements complement or challenge existing citizenship practices, identifying where integration is facilitated and rewarded with citizenship. I also show where civic requirements fill strategic goals, mainly controlling the inflow and impact of immigration. The arguments made here support a critical rethinking of the conventional wisdom about national models of integration and a dynamic understanding of state citizenship strategies, where policies define not only the rules but also the content of national membership.

\subsection{From Entitlement to Experience: Access to Education for Children of Migrant Workers from Burma}

\section{By: Mary Austin}

This article explores the impact of migrant worker registration on access to primary education for the children of Burmese migrants living in Thailand. The first section examines the basis in domestic and international law for migrant children's claim to educational entitlement and questions whether registration affects their claim. This leads to an analysis of NGO and other field-based reports of children and families' lived experience which explores how 
registration interacts with other intersecting forms of discrimination and disadvantage. The final section proposes a framework for evaluating the impact of Thailand's current Nationality Verification scheme from a children's rights perspective.

\section{Research Method}

This paper comes from research result by applying qualitative approach with the main informant is Sebatik District Head and the staff of Educational Institution at Nunukan District, while the informant trilingual informant is this local community. This research is done by applying snowball method. The data is collected by using in-deeth interview and Forum Group Discussion (FGD) from all of stakeholder participants. The key informant is started from the District Head of North Sebatik then pick Hj. Zuraidah (a midwife) as an actor preceding an educational movement in the border area. According to those informants previously then it develops into stakeholders of education movement which is consist of Dompet Dhuafa Foundation, Pertamina and Ar-Rashid Foundation. This research is also completed by family profile that send their children to the school arond this border area. The illustration of this condition explain into figure and profile below:
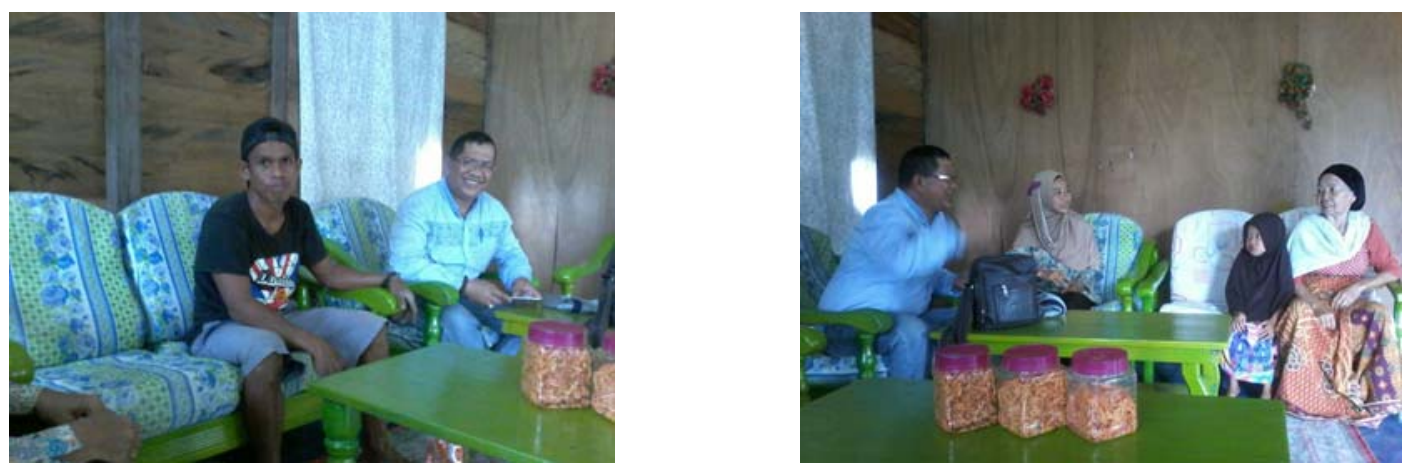

Figure 1. Family Profile who Send Their Children To The School Around Border Area Source: Interview Data

Mr. Nasir whose wear black shirt is one of Indonesia Labor working in Bagosong Besar area, Sebatik Island Malaysia. A mainland with Sebatik Island of Indonesia. He has three children in the age of elementary school, his children cared by his family in Sei Limau Countyside Central Sebatik Sub-District. Mr. Nasir come to his children once in a week, he was working as an Indonesia Labor to pay their school and family. His children names are Nurul Afizah in grade 4 of elementary school, Muh Khairul Admani in Grade 3 of Elementary School and Nurul Ain Asikin in Grade 2 of Elementary School.

\section{Result and Discussion}

This research will illustrate about a social movement generally which is started from various problems faced by community. In time this problem hasn't been solved clearly and the condition will present an actor namely Mrs. Zuraida (As a midwife) into social movement. She challenged to solve this social problem around the border area of Sebatik Island. This period was a critical condition of social movement appearance. In this case, this movement came from her concern of Mrs. Hj Zuraida when giving a partial service found a phenomenon of neglected education for children in the border Country, especiaally for Indonesia Labor. Referring to this condition she expressed an opinion to implement informal education service, and it was received friendly by all communities who need basic educational service.

The next step was strengthening educational social movement who face various obstructions in this implementation such as (location, facility, infrastructure, teacher and fundation). This condition were stimulating an empathy from various stakeholders such as: District-Head and various charities (Dompet Dhuafa Fondation, Pertamina and Ar-Rasyid Fondation).

The last step is the implementation of basic education, organizing and license of an alumnus. When this program were running in a long time finally it has faced hesitance concept among defending of informal status as an education social movement or it will be integrated with conventional program refers to government rule.

\subsection{Educational Complying for All Students}

\subsubsection{The Meaning Social Activity}

In general the meaning of social activity is an activity that consists of real action from various group, informal a large organized, and specifically focuses on a social or political issues with implementing, refused, or promote a social 
change. The social movement is a collective behavior that characterized common interest and long-term goals, namely to change or maintain a community or institution that is in it. Another feature of the social movement is the use of different ways outside of existing institutions (Kamanto Sunarto, 2004:199). The social movement is an effort that is more or less loud and teroganisir are done by people who are realtif large numbers, either to cause change, either to oppose him (Rafael Raga Maran, 2001:67). When formulating or revising regulations for private supplementary tutoring, governments should of course relate their actions to the parallel regulations for schooling (Fielden \& LaRocque 2008; Sergiovanni et al. 2009).

The examples of social movements education is education for all. This call keeps campaigned because access to education has not been the same for several groups of people. Marginal groups from the implementation of this education is not easy to get an education because of various things, so that the Government and people concerned felt it necessary to convene the Special Education known as (PK) and Educational Services known as (PLK) for the marginal groups. The marginal group hereinafter referred to Children in Need Special known as (ABK) which dealt with the special education is a group of intelligent and privileged diffable, are Special Education Services (PLK), developed to serve marginal groups, such as children non diffable from remote, poor communities, Islands, isolated, helpless, and so on.

\subsubsection{Education for Disability Children}

In Indonesia, the Constitutional Laws of 1945 Article 31 and Constitutional Laws Number 20 in 2003 about National Educational System known as (UU SISDIKNAS) mandates that the Government of Indonesia is fully guaranteed to disability students or that have the potential for intelligence and special talents or to acquire quality education services. Education meant which is not differentiated by education services because of a limitation or specificity that is owned by the child. Explained that education is intended for Special Education known as (PK) and Educational Services known as (PLK).

Constitutional Laws of Sisdiknas Article 32 paragraph (1) makes it clear that the definition of special education is education for learners who have difficulty in following the learning process because the disorders are physical, emotional, mental, social, and or have the potential intelligence and special talents; While paragraph (2) makes it clear that the Special Services Education is education for learners in remote areas or underdeveloped, remote indigenous communities, and natural disasters, or having a social disaster, and could not afford in terms of economy.

According to the explanation above, then the Special Education known as (PK) is classified into various groups as follows:

1. Blind

2. Deaf, Dumb

3. Mentally Retarded: Minor: (IQ = 05-70), Middle (IQ = 25-50), (such as Down Syndrome)

4. Tuna Daksha both of Minor and Middle

5. Opium Addict ((Dysruptive), HIV AIDS \& Drug)

6. Autistic, and Sindroma Asperger

7. Double Damage

8. Slow/learning difficulties learn (among others: Hyperactive, ADD/ADHD, Dyslexia, Dysgraphia/write/read/talk, Dysphasia, Dyscalculia/Count, Hyspraxia/Motor).

9. Gifted: potential special intelligence (IQ >130); Multi-talented: special talent potential (multiple intelligences: language, logico-mathematic, visuo-spatial, bodily-kinesthetic, musical, interpersonal, natural, sometimes intrapersonal, spiritual); \& Indigo. Or more commonly known by the term CI \& BI (Intelligent Exceptional and Special Talent)

While Special Education Services (PLK) for children under the age of 18 years including the following:

1. The area underdeveloped/remote/inland/Island, the Child of Indonesian labor (TKI), Indonesia abroad (SILN).

2. isolated minority ethnic Communities (inland tribe)

3. Child workers, child prostitutes, child victims of trafficking, the lapas children, street children, children of scavengers.

4. Refugees (children of earthquake victims, and conflict).

5. Poor extreme/absolute poor. 
So with the notion contained in the regulation of Minister of Women Wmpowerment and Child Protection Number 10 in 2011 article 1 mention of special education and Special Education Services or better known as the Disability Children (ABK) is a child who experiences limitations/exceptionally good physical, mental, social, intellectual or emotional effect significantly in the process of growth and development compared to other children with similar age.

General definition gives a sense of the Disability Children (ABK) is children with special characteristics which are different with children in General without always showed on mental disability, emotional or physical (Heward, 2000). It contains the categories of ABK (disability children), among others, children with visually impaired, deaf, mental retardation, tuna daksha, opium addict, behavior disorders, learning difficulties, gifted children, children with health disorders as well as the limitations of such geographical factors/borders, conflict-prone areas, disaster and other. Article 32 paragraph 2 of the Constitutional Laws of Sisdiknas for Disability Children Marginal consists of:

a. Children victims of social economy, comprising workers of the child, the child scavengers, children goods seller, child prostitutes, child prostitutes, child victims of trafficking, child victims, child drug lapas, child victims of HIV/AIDS, street children, child victims of divorce, orphans, children dropping out of school, poor children absolute

b. Child disaster victims, consisting of the young victims of a natural disaster, the victims of the conflict, the victims of wars, refugee children

c. Geographical berry consist of: children of Indonesia Labor (left behind, isolated, outermost) such as: children of the tribe/inland, the child of the island, childrens in the regions lagging behind

Thus education special services is a kind of education services for children in need of special non dissabilitas or disability children marginal. Special Education Services for children in need of Non-specific Disability/marginal in this research is meant as educational services special for the people that get education/schools with limited geographical factors such as the child of the Islands and in this case is the child of Indonesia labor at the border.

\subsubsection{Educational Movement in the Border Area}

Existence awareness of education in boundary are: early childhood education (OLD), movement for the eradication of illiteracy and education for Indonesia Labor Child (TKI) at the border of Sebatik island ". One of the problems encountered in the border of Central Sebatik districts is a question in the field of education, especially the numbers dropping out of school and illiteracy figures high enough masyakat. The issue is actually by Nunukan District Office of education has been accommodated in a variety programs and activities, but because of the extent of the geographical area of the County coupled with the availability of a limited budget so that the handling of issues in the field of education in the border region has not been fully resolved fine.

Sebatik central Subdistricts in collaboration with the educational institution concerned work together designing and implementing several cooperation programs in order to participate the education address. All stakeholders contribute in addressing the education issue in the education frontier. By utilizing a variety of potential i.e., civic organizations, ultimately in 2012 applied in early childhood Education activities (OLD), eradication of illiteracy and education child for Indonesia Labor in Sebatik. This activity was carried out over the Village and Sub-district government support as well as education service of Nunukan. Technically, the management and organization of the activities carried out by the Ar-Rashid Sebatik Island (one of the agencies concerned with Indonesia Labor child-education) in collaboration with the Organization of mother-homemaker/empowerment of family welfare (PKK) Central Sebatik District.

Thanks to the movement existence, some of the social institution or Government interested and engaged to provide support or assistance. One of the non-governmental a pretty intense help Middle and especially Sebatik community educational institutions run by the Ar-Rashid Foundation is a foundation of Dompet Dhuafa, one of amil zakat institution in Indonesia.

\subsection{Implementation of Educational Movement of the Boundary}

There are at least 3 kinds of movement education in boundary, namely (i) early childhood education (OLD), (ii) the movement of the eradication of illiteracy and (iii) education movement for Indonesia Labor Child /TKI.

\subsubsection{Early Childhood Education}

The large number of Indonesia Labor children who work in palm oil plantations in Sebatik island part of the State territory of Malaysia are "deposited" in the boundary also there needs early childhood education for local people need education service. Although with the minimum facilities, education at this level remains enforceable. Location of education are under houses and used interchangeably with other educational activities, namely the movement for the eradication of illiteracy. PUD managed working with National Education Service of Nunukan District. Until in 2015 already built space for two classes. 


\subsubsection{Movement for the Eradication of Illiteracy}

The number of illiterate in Central sebatik subdistrict in 2012 is quite high. Formerly, before there was a movement for the eradication of illiteracy, of which there are four villages AT Sungai Limau village accounted for a fairly high figure. To address the question of illiteracy for the Community border of Central Sebatik district, then in 2012 implemented practice Functional activities known as (KF) and formed the group that managed the joint between Foundation Ar-Rasyd and PKK Sebatik Subdistrict.
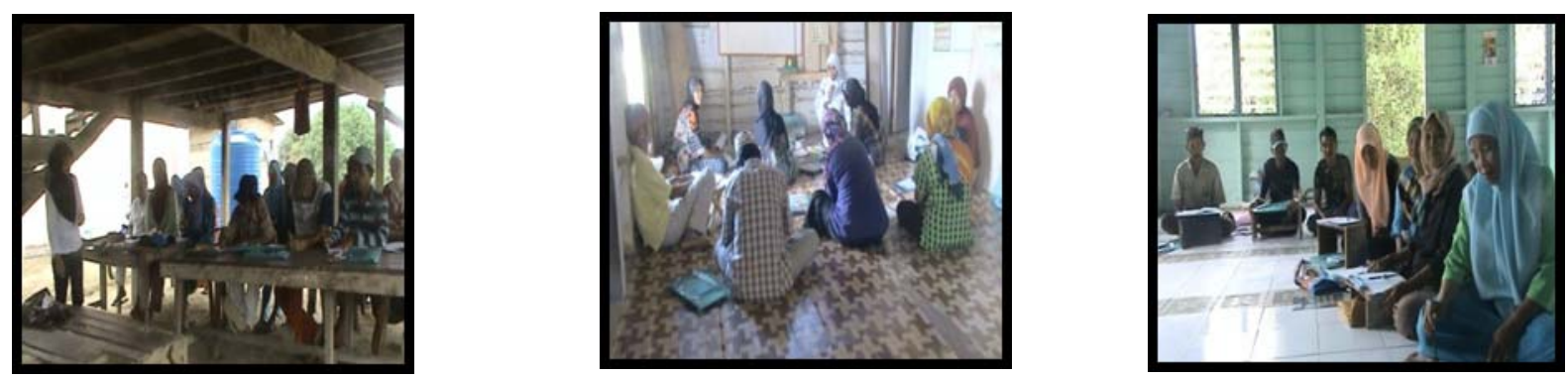

Figure 1. Learning Activities for the eradication of Illiteracy with Functional Literacy

The number of Functional Literacy in the primary grades in 2012 totally is 11 groups from Ar-Rashid Foundation, consisting of 110 children and 5 group from teams the PKK conceptualizer of Central Sebatik Subdistrict consists of 50 children, bringing the total in 2012 as many as 160 children/learners. In 2013 from Ar-Raysid Foundation bring 5 groups consists of 50 children/learners and PKK as much as 5 group consists of 50 children/learners, so that the total amount of 2013 as much as 100 children/learners.

Table 1. Learners Educational Movement at the beginning of the border

\begin{tabular}{|c|c|c|c|}
\hline Year & Organization Executor & Group Amount & Students Amount \\
\hline \multirow[t]{3}{*}{2012} & Ar-Rasyid Foundation & 11 groups & 110 children \\
\hline & PKK & 5 groups & 50 children \\
\hline & Amount & & 160 children \\
\hline \multirow[t]{3}{*}{2013} & Ar-Rasyid Foundation & 5 groups & 50 children \\
\hline & PKK & 5 groups & 50 children \\
\hline & Amount & & 100 children \\
\hline
\end{tabular}

Since from 2012 to 2013 the overall educational level of graduates of this Foundation as many as 260 people, with details as follow:

a) Sungai Limau Village: 20 groups (200 people)

b) Aji Kuning Village: 2 groups (20 people)

c) Bukit Harapan Village: 1 group (10 people)

d) Maspul Village: 3 groups (30 people)

Bases on the implementation program of Functional Literacy (KF) in Central Sebatik sub-district since 2012 has resulted in a reduced number of illiterate. In addition, some communities that have completed the activities of KF continue with General Literacy activities known as (KUM).

One result of General Literacy Program is Village Commissioner in Sungai Limau village which up to now has also produced a product outside of the education field i.e. the assortment of products processed from raw bananas. This Illiteracy Eradication programs also involve teachers/tutors who work with voluntary and Staff come from the village, members of the PKK, the staff of districts, Educators from local people in Central Sebatik.

\subsubsection{Education movement for Indonesia Labor Child (TKI)}

Movement education for Indonesia Labor Child is a movement that arose from the concern will be high number of illiteracy and dropout numbers among the TKI, especially those working in the plantation companies (both run by States as well as by big corporations) are there in Sebatik Malaysia. Due to the absence of institutions founded a company to facilitate the education of children who are in that region, then the TKI "had to" send their children in 
government schools that exist along the land border Sebatik Indonesia. To get to the nearest school, children must walk between 1.5 to 2 hours. For the TKI who have relatives, some are entrusting their children to be accommodated in the homes of relatives who lived in the region of Sebatik Indonesia.
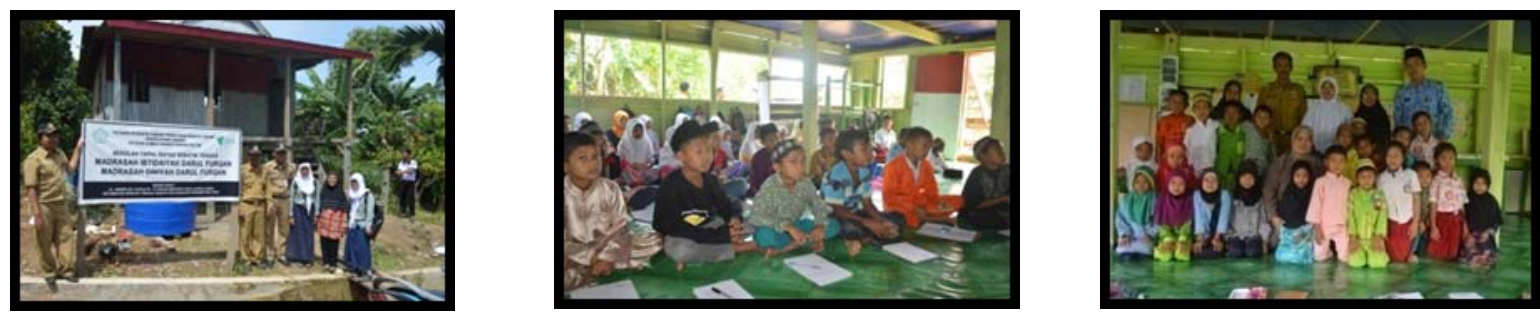

Figure 2. The Education Condition of Indonesia Labor Child

The combination between the exhausting journey and the lure of the ringgit (malaysia's currency) so powerful, as well as awareness of the importance of education is still low is allegedly the cause of ever-increasing numbers dropouts among Indonesia Labor Child. Those who dropped out of school at the later generally helped their parents work in estates-palm oil plantations as well as the existing cocoa plantations in Sebatik Malaysia. Not least among those who have worked and lived in the companies that are in the neighbouring country during two to three generations. Their lives, however, is much to be said deserves due to the low level of education and their competitiveness.

According to the very conditions of concern, then Ar-Rashid Foundation with support from the Government and local Government Sub-district then initiated a shared activity involving Indonesia Labor on the border in order to arouse awareness and to give motivation to keep them more care about the education of their children. Gradually their awareness to education began to grow again and trust to the Government also gradually recovered. There are ideas for organizing a movement education and empowerment a more organized by Ar-Rashid Foundation became the leading sector.

\subsection{The Role of Non Governmental Organisations, Activists and Local Government Education Movement/Sub-District}

\subsubsection{The Role Ar Rasyid Foundation}

Ar-Rashid Foundation is one of the institutions that organise various social movements, education and healthcare in Nunukan Regency, Indonesia. The leader of Foundation Education also becomes Manager of al-Ikhlas education in Nunukan Sub-District Indonesia known by the local government and the local community. When any one of the citizens who are also successful entrepreneurs in Sebatik Central intends to invest its land for the development of education, head of Sebatik Central convey this plan to Al-Rashid Foundation Nunukan. Then this collaboration between Education Foundation, a community activist and local ruler gave birth to massive education movement. Local community leaders, namely the mother Hj. Bidan Suraidah, M.Ns, launch activities with da'wah religious movements, community empowerment, and health services that take in one part of the House residents.

At the request of local citizens, TKI working in Sebatik Malaysia, and support from the local government, then implemented early childhood Education activities known as (PAUD) held in one room loaned by the local citizens. In addition to local children, some of the PAUD learners in these institutions are children of TKI whose parents work at one of the leading palm oil plantation company in the region of Sebatik Malaysia, namely Teck Guan Company. They are dropping off and picking up their kids with crossing borders two countries each day.

It is not only PAUD, activities organized by Ar-Rashid Foundation also later evolved into the activities of health services with the majority patients also Indonesia Labor that working in Sebatik Malaysia, Illiteracy Eradication Program (Self-contained elementary and KF), formation of Village Students, educational Equality (package) and the last is a good Madrasarah Education Diniyah or Ibtidaiya. Recently, PAUD Al-Ikhlas which is managed by this Foundation also became a pilot of PAUD Program Integration Project, Family \& Toddler (BKB) and Health Care Centre for Mothers and Babies known as Posyandu.

In addition to support from the Government, in its activities, Ar-Rashid Foundation also received support and assistance from Dompet Dhuafa Foundation.

\subsubsection{The role of Activist Education}

Profiles education activist is incredible. The name Suraida, because it ever went on Hajj, people called her Mother Hajah Suraida. School boundary pioneered since 2012 and successfully established in 2014 initiated a mother who works as a Midwife named Hj. Suraidah, S.SKM, M.NSc and supported by the head of Central Sebatik Mr. Harman, S.IP, MSi., as well as the citizens of Central Sebatik Mr. Sudarman self-described village chief, Ustad H. Firman take a 
profession as teacher of Islamic religion, Mr. Stevent as community leaders.

The mother Hj. Suraidah set her feet even until settled in Sebatik island of North Kalimantan was never imagined before. The mother Hj. Suraidah birth in Rappang, South Sulawesi, Indonesia, on December 2, 1954, felt very concerned against the fate of Indonesia Labor Child who work in the garden of oil palm in Sebatik, Malaysia. She began opening early childhood Education activities known as PAUD and that most of its students are the children of TKI.

The curious of Indonesia Labor destiny in Bergosong, Malaysia takes her brave on border area. The Mother of Suraidah wishes for notice directly of the community condition around this place, although the consequence is she should face police guard in the border. Her effort gives a result, she gets a lot of information relates to the real condition of Indonesia Labor that is working in the palm company owned by Malaysia.

Bases on information gotten from Indonesia Labor and her affection to children and United Nations so is education, creating The Mother of Suraidah intention so flare up to build school in Central Sebatik District. Her ideas are welcomed nice by all community of Central Sebatik District such as Mr. Sudarman, Mr. H. Firman, and Mr. Steven whose is struggling directly to build this border school in Central Sebatik.

Social movements Education of Boundary State of Indonesia Republic-Malaysia is initiated by the mother Hj. Suraidah with moral support, and material from the communities of Central Sebatik and also spiritual she got during the running of the Hajj. Mother Suraidah feel what she got during the running of the Hajj is a mandate that must be implemented and championed.

According to the village head (Sudarman), the personality of the mother $\mathrm{Hj}$. Suraidah is soft, intimate and unpretentious also concern for the fate of the children nation make Mr. Sudarman was determined to help the struggle of the $\mathrm{Hj}$. Suraidah to realize her ideas, let alone $\mathrm{Hj}$. Suraidah has captivated the hearts of the parents either in Central Sebatik Indonesia or parents in Bergosong Malaysia. Because the ideas of the mother Hj. Suraidah makes the parents who want their children get education already impatient and often asked Councilor when ideas of the mother Hj. Suraidah it materialized.

Information from Father Ustad H. Firman, Mother Hj. Suraidah figure of woman-friendly, kind, and smart also has a fairly high faith in religious preaching movement prove that not only performed at the Mosque but also they move with go to the citizens. In addition the condition of Indonesia Labor in Bergusung not provided a place of worship is also an education makes the father of Ustad H. Firman of the determined support of the mother Hj. Suraidah to embody his ideals in setting up schools in Central Sebatik District later children would get an education and religious science.

Information from Steven (community leaders) that $\mathrm{Hj}$. Suraidah is the figure of the woman who has everything, in terms of a gentle personality, attention to people who have not had time to feel the World Education attested by teach the illiterate communities to get to know the letters to be read, and that was done by the mother Hj. Suraidah selflessly without expecting rewards. The mother of $\mathrm{Hj}$. Suraidah always sharing science to society and affection towards the children of the nation make the hearts of Mr. Steven wanted to help realize the her ideals. With struggle with Mr. Sudarman, father of Ust. H. Firman and the father of the Head and mother of Hj. Suraidah so that the school stood a poultice which consists of Early Childhood Education, package A (eradication of Illiteracy), and the Madrasa.

\subsubsection{The Role of The Local Government}

The establishment of the School Boundary has been helping communities to meet the needs of children's education of villages at the border and including Indonesia Labor Child in adjacent to Central Sebatik called as Bergosong. At this time (2017) the number of students as much as 122 students, consisting of Early Childhood Education Levels, Madrasa Ibtida'iyah (MI) and Madrasah Diniyah (MD). School Boundary also get support from the Ministry Religion of Indonesia Republic in Nunukan Regency, The Government of East Kalimantan province, Dompet Duafa, The Government of Nunukan Regency which always helps in terms of administration and operations.

In order to make the movement of the eradication of illiteracy and education facilitation for Indonesia Labor Child, Central Sebatik Regency took a role with organise functions of planning, coaching, coordination and also get involved directly in the implementation through the PKK organization Subdistrict or assigning volunteer teachers to teach. This Regency also hosts these monitoring and evaluation activities of the events course.

\subsubsection{Planning}

The involvement of local government (sub-district) in planning the form formulation strategy approach to society and Indonesia Labor. Planning activities will not be successful without the support and active participation from the community. Local governments help the Foundation to design the model approach is effective in increasing public confidence towards the institutions. Whereas the implementation of the strategy and planning, generally carried out by 
the Foundation along with other strategic partners.

\subsubsection{Coordination}

In addition to community education and empowerment, the movement for communities border and Indonesia Labor involves some local organizations, whether local governments with different levels of military organization, the border police, as well as some social institutions namely Ar-Rashid Foundation and Dompet Dhuafa Foundation. Local government/ Sub-District function performs coordination to help synergize the activities, including promoting these activities in order to encourage the stakeholder involvement.

\subsubsection{Implementation}

The involvement of Sub-District are represented by women's organizations or PKK Sub-District or volunteer teachers who are also staff of the district, as well as the mutual society movement in the construction of the school building. $P K K$ was directly involved in the Organization of several functional literacy groups, promotional product results processed from a group of students in the village. While the staff of the Sub-District volunteer teachers in educational equality. The involvement of the other sub-district is in the form of awarding honoraria for Teachers Program Equality organized by the Foundation in Sebatik Malaysia. Honor teachers in question are taken from the Community/charity funds collected in the Sub-District Office environment of Central Sebatik. The support Government Sub-District is also supplying equipment, mutual development and maturation of the school boundary currently being the center of Ar-Rashid Foundation activities.

\subsubsection{Monitoring}

Monitoring activities is quite intense conducted by the Sub-District Government including accompanying guests who visit do visitasi in activities carried out by the Foundation.
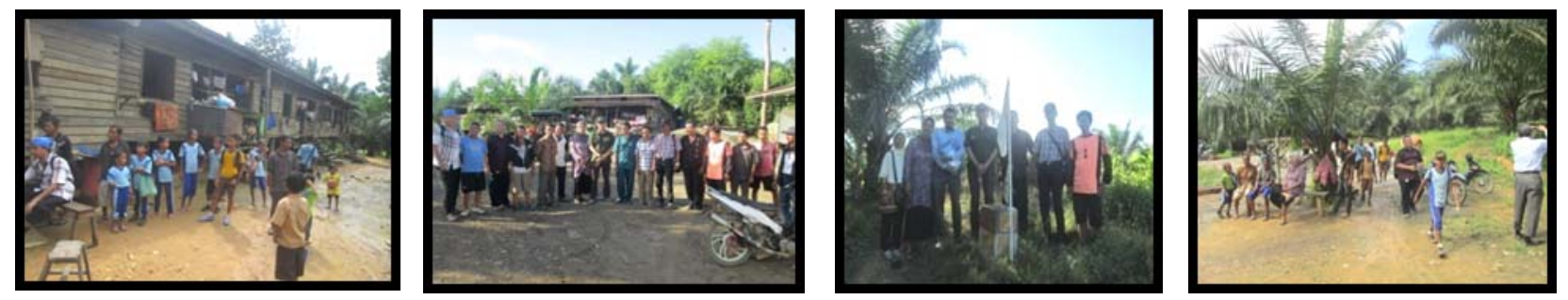

Figure 3. The Visitation of Indonesia Labor Camp of Sebatik Malaysia

\subsubsection{Evaluation}

Central Sebatik Sub-District is also active in implement evaluation activities. In addition to running the function of Sub-District, this evaluation was also done by the District Head in order as Trustees/Advisors at school Boundary.

\subsubsection{Dompet Duafa Foundation}

Dompet Duafa (the name of a Social organisasil in Indonesia) provides assistance to School Boundary in 2014 in the form of revitalisai building which was originally the building was just a frame converted into a home and school. Next dompet dhuafa also provides assistance in the form of awarding honoraria for teachers, teachers and operations of healthy eating. Every year dompet dhuafa also strives to enhance competence of teachers in two ways namely massive and thorough way. How massive is raising a teacher competence inviting teachers in training undertaken in other areas such as teacher training in Bogor. While a thorough way is to increase the teachers competence and school management by bringing in teachers to suit the needs of the school known for its educational programs of Indonesia literature. Educational program of Indonesia Literature School Boundary given to Madrasah Ibtidaiyah. In addition to assisting in the development of the competency of the teachers were also given management training school by hoping this Madrasah Ibtidaiyah for future became an independent school.

\subsection{The Restricting Factor of The School Boundaries Movement}

Movement education border still mostly encountered obstacles, among others: still the lack of support, whether the public at large, the Central Government, the local population as well as corporate. However there is such attention had already begun of Dompet Dhuafa and Pertamina. Expressed by the head of South Sebatik (Harman, SIP, MSi.):

"That needs attention is the learning space for students of Madrasah Ibtidaiyah and Madrasah Diniyah, Sir. It would be more elegant if boarding schools to be built, so that the Indonesia Labor Child do not need round trip across the country every day”. 
The obstacles still faced in the development of education in border Sebatik island is among others, are:

a. Human resources educators are still skimpy, either quantity or quality. Currently the majority of educators are using Senior High School Degree or equivalent. The very lack of teachers make teaching and learning are not effective. Teachers current numbering 8 people, 3 people including Bachelor Degree backgrounds, while 5 others educated Senior High School Degree. The number of teachers is certainly not comparable to the number of pupils who are no proportionate as much as 130 students, with details of the 31 students of Early Childhood Education and 36 students of Madrasah Ibtidaiyah, and 63 students of Madrasah Diniyah students. Ar-Rashid Foundation also experienced difficulty in finding teachers, because most of the prospective teachers require salaries/honorarium which is not yet to be met by the Foundation. The source of the funds of Ar-Rashid Foundation is only the support from stakeholders and do not have donors anyway.

b. The schools locations, is join in the space under community house. Loan for 7 years (since 2012). Facilities and learning media is very minimal. The buildings used by the Ar-Rashid Foundation for teaching and learning activities is loaned by the homeowner for a period of 7 years. The buildings are made of wood measuring approximately $6 \times 8$ meters and has 2 floors. The 1st floor is used for the teaching and learning activities in the boundary into 3 parts so it looks very narrow once and any learning hours divided into 4 shiff in the day which starts from 06.00 until 17.30. The 2nd floor of the building was used for a library and a place to stay of teachers and students. As for the number of teachers who stay as much as 4 people while the students who stay as many as 12 people. They stay because of the distance between the residence towards the school are very far. Limitations of operational costs. Operational costs and living costs of students (there are 11 of Indonesia Labor Child who settled in the location) is only relying on donors and partners (Dompet Dhuafa).

c. Low level education of student parents causing they assume that the school was not important. Their children were told to help out gardening, because the crops they pick is very large and profitable, so without attending school any children they can still eat and fulfilled their life necessities.

d. The distance among residence parents and school location are far. To get to schools, teachers and students have to walk as far as approximately $5-10 \mathrm{Km}$, passing through the hilly area, the cobbled streets and even across the river/sea due to the lack of public transportation. Even when the rainy season arrived most of the students do not attend school because of the path that is skipped is very muddy, slippery and muddy.

\section{Conclusion}

The social movement is a collective behavior that characterized common interest and long-term goals, namely to change or maintain a community or educational institution that is in it. Another feature of the social movement is the use of different ways outside of the usual way. Not just how but also the institutions that handle education services are also different, beyond naturalness. Education as the basic needs of the community in the border regions of Indonesia and Malaysia in particular of South Sebatik District, as well as other social movements have used different ways with the Organization of education not only for locals but by and for all Indonesia citizens even though it is not a local resident. Managed by the community work together with various civic and a pillar of the local government.

The handling question of the border is not only become the responsibility of the Central Government, provincial government, and the Government district/city alone but also will need to be supported by all components of the nation both from the corporate world, community organizations and agencies/other technical institutions. Starting from the large number of issues in the border area, then needed an innovation and creativity from the organizers of Government at the level of districts and Villages as the Border becomes the home front of Indonesian Republic. The attitude of society to care about the borders should look for solutions and solving the problem.

School Boundary, South Sebatik District held some type of education: Early Childhood Education known as (PAUD), Madrasah Ibtidaiyah (Elementary School/formal level), Madrasah Diniyah (Non Formal Elementary School), package A, B and C as well as Functional Literacy (KF)/General Literacy (KUM). Early Childhood Education students, Madrasah Ibtidaiyah and Madrasah Diniyah come from Indonesia Labor Child that is working in plantations Palm in Sebatik Island which became Malaysia country area. In Sebatik Malaysia currently there is also a class Package A. thus School boundary is the identity of education that hosts a variety of educational services program. As a social movement, this boundary education must always be raised spirit and--by continuing to address the problems at hand.

This research has its limitations, which is only focused on the efforts of the Organization of the education service by the Community border in Indonesia, not much special education services information worker conducted by society and the State on the border of Malaysia.

\section{Acknowledgement}

This research aimed to developing scientific field in Department of Public Administration and to stimulate an interest 
relating to educational neglected in the border area arounf this world. This research supported by Diponegoro university Institution that has been supported a research process as well as resource classification around sebatik area malaysia (border area among Indonesia and Malaysia).

\section{References}

Arikunto, S. (2007). Dasar-dasar Evaluasi Pendidikan (Edisi Revisi) (The Basis of Educational Evaluation (Revision Edision)) Jakarta: Bumi Aksara.

Arikunto, S. (2007). Evaluasi Program Pendidikan (The Evaluation of Educational Program). Jakarta: Bumi Aksara

Austin, M. (2012). From Entitlement to Experience: Access to Education for Children of Migrant Workers from Burma. Asian and Pacific Migration Journal, 21(3). https://doi.org/10.1177/011719681202100307

Daryanto, H. M. (2006). Administrasi Pendidikan (Educational Administration). Jakarta: Rineka Cipta.

Farahania, M. F., \& Arani, N. A. (2014). Border Education with Emphasizing on Giroux's Educative Implications. Procedia - Social and Behavioral Sciences, 116, 1423-1427. https://doi.org/10.1016/j.sbspro.2014.01.409

Fielden, J., \& LaRocque, N. (2008). The Evolving Regulatory Context for Private Education in Emerging Economies: Discussion Paper. Washington DC: The World Bank and International Finance Corporation.

Goodman, S. W. (2010). Integration Requirements for Integration’s Sake? Identifying, Categorising and Comparing Civic Integration Policies. Journal of Ethnic and Migration Studies, 36(5), $753-772$. https://doi.org/10.1080/13691831003764300

Jaluluddin, \& Idi, A. (2007). Filsafat Pendidikan (The Philosophy of Education). Yogyakarta: Ar-Ruzz Media.

Kasetsart, W. N. (2016). The Important Factors of English Program Administration Responsive to the ASEAN Community for Schools in the Border Provinces of Southern Thailand. Journal of Social Sciences, 37, 158e163

Lan, J. (2012). Feasibility Analysis of Developing Cross-Border Network Education in China. Physics Procedia 33, 1979-1985. https://doi.org/10.1016/j.phpro.2012.05.311

Nitjarunkul, K. (2015). The Study of Concepts Understanding and Using Competence of Teachers in Educational Innovation and Technology for Teaching Management at Schools of the Unrest Areas of Three Southern Border Provinces of Thailand. Procedia - Social and Behavioral Sciences, 174, 2473-2480. https://doi.org/10.1016/j.sbspro.2015.01.919

Rafael Raga Maran, Pengantar Sosiologi Politik (Introduction to Political Sociology). Jakarta: Rineka Cipta, 2001.

Studzieniecki, T. (2016). The Development of Cross-Border Cooperation in an EU Macroregion -a Case Study of the Baltic Sea Region. Procedia Economics and Finance, 39, $235-241$. https://doi.org/10.1016/S2212-5671(16)30318-5

Suharto, S. (2009). Kemiskinan \& Perlindungan Sosial di Indonesia (The Poverty and Social Protection in Indonesia). Bandung: Alfabeta.

Sunarto, K. (2004). Pengantar Sosiologi (Introduction to Sociology). Jakarta: Lembaga Penerbit Fakultas Ekonomi Universitas Indonesia.

T.Keban, Yeremias. (2008). Enam Dimensi Strategis Administrasi Publik (Six Strategic Dimensions of Public Administration), Yogyakarta: Gava Mdia.

Tilaar, H. A. R. (2002). Manifesto Pendidikan Nasional Tinjauan dari Postmodernisme dan Studi Kultur (National education manifesto review of Postmodernism and Cultural Studies). Jakarta: Kompas.

Tilaar, H. A. R. (2006). Standarisasi Pendidikan Nasional suatu Tinjauan Kritis (National Education Standards a Critical Review). Jakarta: Rineka Cipta.

Zuriah, N. (2007). Pendidikan Moral dan Budi Pekerti dalam Perspektif Perubahan (Moral education and Manners in the perspective of change). Jakarta: bumi Aksara.

\section{Copyrights}

Copyright for this article is retained by the author(s), with first publication rights granted to the journal.

This is an open-access article distributed under the terms and conditions of the Creative Commons Attribution license (http://creativecommons.org/licenses/by/4.0/). 